\title{
PENINGKATAN KEMAMPUAN BERBICARA BAHASA ARAB MELALUI METODE PERCAKAPAN
}

\author{
Nurdiniawati dan Syafruddin \\ (dininurdiniawati@gmail.com)
}

(Dosen Tetap Fakultas Tarbiyah IAI Muhammadiyah Bima)

\begin{abstract}
الملخص
الطربقة المحادثة هي إحدى الطرق المستخدمة لتسهيل الشخص في مهارة الكلام. طلاب الصف الحادي عشر في المدرسة الثانوية دار الفرقان يجدون صعوبة في كلام اللغة العربياة. تهدف هذا البحث لمعرفة تطبيق الطربقة المحادثاة لترقية مهارة الكلام اللغة العربية للطلاب الصف الحادي عشر في المدرسة الثانوية دار الفرقام مدينة بيما. نوع البحث يعني البحث الإجرائي الصفي وطريقة جمع البيانت

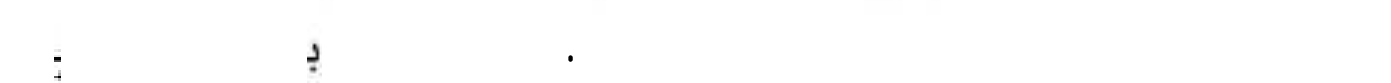

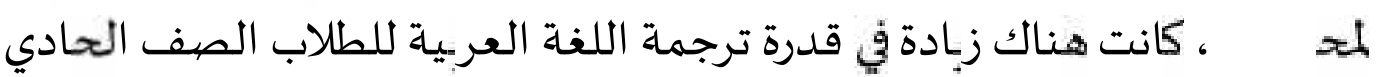

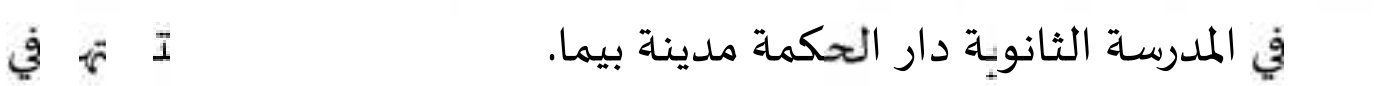

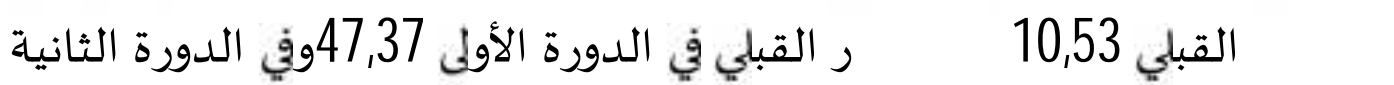

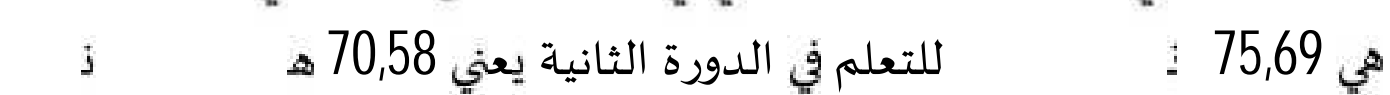
النجاح الطلاب يحققون معايير النجاح وعي 75,69 من جمبع الطلاب.
\end{abstract}

\author{
الكلمات المفتاح: الطر:قة المحادثة ، قدرة ترجمة اللغة العربية
}

Metode percakapan merupakan salah satu metode yang digunakan dalam pembelajaran bahasa Arab khususnya dalam maharah kalam. Siswa kelas XI MA Darul Furqan merasa kesulitan dalam berbicara bahasa Arab, hal ini dikarenakan siswa kurang berinteraksi dengan menggunakan bahasa Arab. Penelitian ini bertujuan untuk mengetahui penerapan metode percakapan terhadap peningkatan kemampuan berbicara bahasa Arab siswa kelas XI MA Furqan Bima. Jenis penelitian ini adalah PTK dan metode pengumpulan data menggunakan observasi, wawancara, test dan dokumentasi. Hasil penelitian menunjukkan bahwa setelah menerapkan metode percakapan terdapat peningkatan kemampuan berbicara bahasa Arab siswa kelas XI MA Darul Furqan Bima. Hal ini dapat dilihat pada nilai rata-rata siswa pada tes awal 10,53 dan tes akhir Siklus I 47,37, pada tes 
akhir siklus II adalah 75,69 dan persentase ketuntasan belajar pada siklus II adalah 75,69 \% yang berati bahwa persentase ketuntasan belajar siswa sudah memenuhi kriteria ketuntasan yaitu $75 \%$ dari keseluruhan siswa.

Kata Kunci: Metode Percakapan, Berbicara, Bahasa Arab.

\section{A. PENDAHULUAN}

\section{Pengertian bahasa Arab}

Bahasa Arab merupakan bahasa yang istimewa di mata dunia. Sebagaimana kita ketahui bahwasannya bahasa Arab tidak hanya bahasa peninggalan peradaban orang Arab kuno, melainkan bahasa yang digandrungi para ilmuwan dewasa pada saat ini. Bahasa Arab merupakan bahasa Al- Qur'an dan mempunyai retorika yang bagus dibandingkan dengan bahasa-bahasa lainnya. Bahkan bahasa tersebut selain bahasa orang Arab, juga merupakan alat dakwah bagi umat Islam. ${ }^{1}$ Bahasa Arab adalah bahasa Al-Qur'an dan Al-Hadist yang diturunkan oleh Allah SWT di Mekkah dan diwahyukan kepada Nabi Muhammad SAW sebagai risalah kebenaran atas kemukjizatan Islam yang nyata, dan merupakan bahasa yang dipakai dalam bacaan sholat yang dilaksanakan oleh umat Islam di seluruh Dunia.

Dalam bahasa Arab bahasa disebut lugah yang bermakna ucapan manusia, sehingga semua suara yang diucapkan oleh manusia disebut dengan lugah (bahasa). Definisi ini adalah pengertian dalam bahasa Arab pada zaman dahulu dan zaman jahiliyah, tetapi seiring dengan perkembangan zaman pengertian lugah (bahasa) ini mengalami penyempitan makna, sehingga yang dimaksud bahasa pada zaman kita sekarang adalah dialek bangsa tertentu atau bahasa bangsa tertentu. ${ }^{2}$ Sedangkan pengertian bahasa menurut istilah ada beberapa pendapat, yaitu:

a. Menurut Ibnu Jinni, bahasa adalah suara-suara yang diungkapkan oleh setiap orang untuk mengungkapkan keinginan-keinginannya.

\footnotetext{
${ }^{1}$ Ahmad Izzan, Metodologi Pembelajaran Bahasa Arab. (Bandung: Humaniora 2004 ), 5.

${ }^{2}$ Fathur Rohman, Metodologi Pembelajaran Bahasa Arab,(Malang: Madani, 2015), 1.
} 
b. Menurut Ibnu Hazm, bahasa adalah lafadh-lafadh yang digunakan untuk mengungkapkan nama-nama sesuatu, mengungkapkan makna-makna yang maksudnya telah difahami.

c. Menurut Ibnu Khaldun, bahasa adalah ungkapan seseorang pembicara tentang maksud yang ia inginkan. Ungkapan itu adalah perbuatan mulut yang muncul dari suatu niatan untuk mengatakan, sehingga anggota tubuh yang mengungkapkan itu berupa mulut.

d. Menurut para ahli bahasa modern, bahasa adalah aturan urfi berupa rumusrumus bunyi yang digunakan oleh manusia untuk berkomunikasi dengan orang lain.Dari beberapa definisi ini kita dapat mengetahui bahwa ada yang menyebutkan bahasa itu adalah bunyi atau suara dan ada yang mengatakan bahwa bahasa itu adalah rumus atau aturan, tetapi yang sama dalam semua definisi itu adalah bahwa bahasa itu digunakan oleh seseorang untuk mengungkapkan keinginannya, perasaannya dan apa yang ada dalam fikirannya. ${ }^{3}$

\section{Fungsi Bahasa Arab}

Bahasa Arab itu memiliki beberapa fungsi -fungsi itu adalah sebagai berikut:

a. Bahasa Arab membawa dasar-dasar agama Islam yang benar dengan cara ditetapkannya sebagai bahasa al-Qur'an al-karim.

b. Bahasa Arab itu ditegakkan dari unsur-unsur bangsa Arab, kerena bahasa Arab memberikan legalitas kepribadian bangsa dan memperkuat identitas bangsa Arab, serta menjadi alat komunikasi di antara umat Islam.

c. Bahasa Arab tidak diajarkan secara tersendiri, karena sebenarnya semua peserta didik itu mempelajari ilmu-ilmu yang lain.

d. Bahasa Arab menjadi media percontohan untuk menjaga warisan budaya Arab. Hal itu dibuktikan dengan warisan budaya dan peradaban bangsa Arab yang telah sampai pada kita saat ini seperti peradaban, karya sastra, sya'ir dan prosa. $^{4}$

\footnotetext{
${ }^{3}$ Ibid.,2
}

${ }^{4}$ Ibid., 15 
Setelah banyak orang yang mengalami kemajuan, tujuan belajar bahasa Arab bukanlah untuk memberantas penduduk yang buta huruf saja, sebab tujuan itu sudah jelas, meskipun demikian hal itu harus tetap menjadi tujuan selama kebodohan itu masih ada, tetapi tujuan mempelajari bahasa Arab yang penting adalah membekali orang-orang agar mampu membaca dan menulis sehingga mereka mengerti sejarah, masa depan, dan lebih banyak mengambil pelajaran dari para pendahulunya. Untuk meningkatkan perkembangan pembelajran bahasa Arab dilembaga pendidikan perlu adanya penciptaan strategi inovatif dari guru bahasa Arab agar tujuan pembelajaran bahasa Arab tercapai dengan baik. ${ }^{5}$

Jadi tujuan utama mempelajari bahasa Arab adalah mampu mengungkapkan dengan menggunakan bahasa Arab, karena itu adalah alat untuk saling memahami dan barometer sebuah kefahaman. Peserta didik harus dapat mengungkapkan keinginannya atau apa yang ada dalam fikirannya dengan sempurna dan benar, baik secara lisan atau tulisan. Peserta didik mampu memahami apa yang dia baca atau apa yang dia dengarkan, dan dia bisa ikut serta dalam berfikir sesuai dengan kemampuannya, usianya, dan kegemarannya. ${ }^{6}$

Kemahiran berbahasa Arab adalah merupakan salah satu jenis kemampuan yang ingin dicapai dalam pengajaran berbahasa Arab, karena bahasa Arab merupakan sarana utama untuk berkomunikasi dengan orang Arab dan memahami buku atau kitab yang berbahasa Arab. Maka diperlukan pengoptimalan belajar dan mengajar bahasa Arab didalam instansi pendidikan formal maupun nonformal. Untuknya, upaya-upaya pengotimalan kegiatan belajar mengajar sangat tepat dilakukan demi meningkatkan kualitas pendidikan bahasa Arab.

Menurut Tarigan dalam buku Acep Hermawan bahwa keterampilan berbicara merupakan kombinasi faktor-faktor fisik, psikologis, semantik, dan linguistik secara luas, sehingga dapat di anggap sebagai alat manusia yang paling penting bagi control social sacara umum katerampilan berbicara bertujuan agar para pelajar mampu berkomuniaksi yang baik dan benar dengan bahasa yang mereka pelajari. Namun untuk mencapai tahap kepandaian dalam berkomunikasi

${ }^{5}$ Muspika Hendra, "Pembelajaran Keterampilan Berbicara bahasa Arab Melalui Pendekatan Komunikatif”,Potensia jurnal Kependidikan Islam, No.2, Volume 3 (Desember, 2017), 199.

${ }^{6}$ Rahman., Metodologi Pembelajaran. 28. 
diperlukan aktivitas - aktivitas latihan yang memadai dan mendukung. Dalam hal ini dalam buku Acep Hermawan, subyakto-nababan membagi aktivitas ini kedalam dua kategori, prakomunikatif dan komunikatif. ${ }^{7}$

Pembelajaran bahasa Arab merupakan proses tranformasi ilmu, sikap mental dan prilaku kebahasaan Arab yang diharapkan dapat dilakukan secara professional dan berorientasi kepada tujuan tertentu.Tujuan bahasa Arab dapat di realisasikan secara efektif jika dilandasi oleh visi, misi dan orientasi yang jelas terhadap prosedur yang dilakukan berlandaskan strategi, pendekatan dan metode yang tepat dan relevan dan akhirnya menghasilkan output yang optimal dan memuaskan baik bagi peserta didik, guru maupun lembaga pendidikan dan masyarakat luas.

Jadi, fungsi utama belajara bahasa asing itu adalah kemampuan berhasa aktif, berkomunikasi lisan atau bercakap - cakap. Itulah tujuan utama atau target pokok dalam mempelajari bahasa asing,disusul kemampuan membaca dan memahami atau penguasaanpasif,

Oleh karena itu, metode utama dan pertamanya didalam belajar dan mengajar bahasa asing itu semestinya adalah metode percakapan (conversational method) metode ini disejalankan dengan direct metode dan natural method, yang pelaksanaannya dan menerapkan fungsi dan prinsip - prinsip ketentuan dari tiap - tiap metode itu. ${ }^{8}$

Untuk itu, diperlukan sekali pembelajaran yang efektif yang merupakan suatu upaya untuk mengetahui berhasil tidaknya pelaksanaan pembelajaran bahasa, khususnya bahasa Arab,baik dari segi proses maupun hasil. Oleh karena itu peran seorang guru tidak cukup sebagai pengajar saja, di samping pengajar bahasa Arab seorang guru bahasa Arab harus menjadi pakar ataupun menguasai perbendaharan bahasa Arab atau retorikanya.

Dalam hal pembelajaran bahasa Arab, pelajaran muhadatsah merupakan pelajaran bahasa Arab yang pertama-tama diberikan. Sebab tujuan utama pengajaran bahasa Arab adalah agar peserta didik mampu bercakap-cakap

\footnotetext{
${ }^{7}$ Acep Hermawan, Metodologi Pembelajaran Bahasa Arab. ( Bandung: PT. Ramaja Kosdakarya 2018 ), 195

${ }^{8}$ Ahmad Izzan, Metodologi Pembelajaran Bahasa Arab. (Bandung: Humaniora 2004 ), 90 - 91
} 
(berbicara) dalam pembicaraan sehari-hari dengan berbahasa Arab dan membaca Al-Qur'an, dalam sholat dan do'a-do'a. Metode muhadatsah merupakan cara menyajikan bahan pelajaran bahasa Arab melalui percakapan, dalam percakapan itu dapat terjadi antara guru dan murid dan antara murid dengan murid. Sambil menambah dan terus memperkaya perbendahraan kata-kata (vocabulary) yang semakin banyak.

Faktor yang terpenting dalam menghidupkan kegiatan muhadatsah (berdialog) adalah keberanian peserta didik dan tidak takut salah. Oleh karena itu guru harus dapat memberikan motivasi kepada peserta didik agar mereka berani bermuhadatsah kendati beresiko salah. Hendaknya para peserta didik diberi wejangan bahwa takut salah dalam belajar bahasa adalah suatu kesalahan besar.

Sebab takut salah dan malu adalah hambatan untuk bias terampil bahasa Arab. Peserta didik mulai dari tingkat dasar telah diharuskan bercakap-cakap dengan bahasa Arab disamping bahasa Inggis, meskipun mula- mula arti pembicaraan belum begitu dipahami tapi lama-kelamaan sedikit demi sedikit peserta didik mulai mengerti dan memahaminya.

\section{B. METODE PERCAKAPAN}

\section{Pengertian Metode Percakapan}

Metode percakapan ( conversation method) yaitu metode pengajaran bahasa asing seperti bahasa bahasa Arab, atau bahasa - bahasa lainnya dengan cara langsung mengajak murid bercakap - cakap / berbicara di dalam bahasa asing yang sedang diajarkan itu. Tentunya di mulai dengan kata - kata atau kalimat - kalimat atau ungkapan - ungkapan yang biasa berlaku pada kegiatan - kegiatan sehari - hari, seperti كيف حالك؟dan lain sebagainya; atau kalimatkalimat percakapan di dalam kelas, di sekitar sekolah, dirumah, di kantor dan lain sebagainya; semakin lama semakin luas, dan beragam percakapan.

Metode muhadatsah yaitu cara menyajikan bahasa pelajaran bahasa Arab melalui percakapan, dalam percakapan itu akan terjadi antara guru dan murid dan antara murid dengan murid sambil menambah dan terus memperkaya 
pembendaharaan kosa kata yang semakin banyak. ${ }^{9}$ Jadi metode utama dalam kegiatan belajar dan mengajar bahasa asing itu semestinya adalah metode percakapan. Metode ini di sejalankan dengan Direct Methot dan Natural Method, yang pelaksanaannya dengan menerapkan fungsi - fungsi dan prinsip ketentuan dari tiap - tiap metode itu.

\section{Kelebihan dan Kekurangan Metode Percakapan}

Ada beberapa kelebihan metode muhadatsah adalah:

a. Dapat mengaktualisasi isi materi secara langsung.

b. Menimbulkan keberanian dalam bermuhadatsah

Dan ada beberapa kelemahan dari muhadatsah adalah:

a. Metode ini di pergunakan dalam level tertentu

b. Kurangnya dominasi guru terhadap metode ini, pada umumnya pengajaran pada Indonesia memakai metode usang (Qawaid Tarjamah).

\section{Manfaat Metode Percakapan}

Ada beberapa manfaat metode percakapan adalah:

a. Dapat meningkatkan kemampuan berbicara bahasa Arab pada peserta didik.

b. Siswa mampu mempraktekan hasil pelajaran metode percakapan yang di ajakan oleh gurunya terhadap teman sekitanya.

c. Dan mengimplentasikan apa yang diajarkan oleh gurunya.

\section{Langkah - Langkah Metode Percakapan}

Pembelajaran bahasa Arab dengan menggunakan metode muhadatsah dapat di lakukan dengan langkah-langkah berikut:

a. Mempersiapkan materi dialog dan menetap kantopik yang akan disajikan secara tertulis.

b. Materi muhadatsah hendaklah disesuaikan dengan taraf perkembangan dan kemampuan peserta didik.

${ }^{9}$ Ibid, 116 
c. Menggunakan alat peraga sebagai alat bantu muhadatsah. Sebab dengan adanya alat peraga dapat menjelaskan persepsi anak.

d. Tentang arti dan maksud yang terkandung dalam muhadatsah. Selain itu, dapat menarik perhatian peserta didik dan tidak menjenuhkan. Pendidik hendaknya menjelaskan terlebih dahulu arti kata yang terkandung dalam muhadatsah sesuai dengan yang ditampilkan. Setelah peserta didik dianggap mengerti, mereka diminta untuk mempraktekkan didepan kelas dan teman lainnya menyimak dan memperhatikan sebelum ia mendapat giliran berikutnya.

e. Untuk tingkat lanjutan, pendidik hanya menentukan topic dan mengatur jalannya proses pembelajaran. Selanjutnya peserta didik mengambil peran lebih banyak ketika proses pembelajaran berlangsung.

f. Pendidik hendaklah menggunakan bahasa Arab ketika proses pembelajaran berlangsung.

g. Pendidik hendaklah menetapkan batasan materi untuk pertemuan berikutnya, agar peserta didik lebih mempersiapkan diri untuk materi berikutnya.

Langka-langkah diatas tidaklah bersifat kaku. Pendidik bias membuat modifikasi pembelajaran sesuai dengan kondisi kelas yang dihadapi. Seperti pada poin 6, yang menuntut pendidik menggunakan bahasa Arab ketika proses pembelajaran berlangsung.

\section{METODE PENELITIAN}

Kegiatan penelitian merupakan salah satu upaya manusia dalam memenuhi rasa ingin tahunya. Apabila rasa ingin tahu itu membutuhkan kebenaran yang berkriteria keilmuan maka hal tersebut dapat disebut masalah keilmuan. Masalah seperti itu memerlukan jawaban dengan kerangka berpikir tertentu, yaitu digunakannya metode keilmuan atau memerlukan kegiatan. ${ }^{10}$

10 Suharsimi Arikunto, dkk, Penelitian Tindakan Kelas, (Yogyakarta: PT Bumi Aksara, 2008), 142 
Jenis penelitian yang digunakan dalam penelitian ini adalah penelitian tindakan kelas (PTK), yang termasuk dari bagian penelitian eksperimen atau uji coba. $^{11}$

Suyadi memaparkan, penelitian tindakan kelas terdiri atas tiga kata, yaitu penelitian, tindakan, dan kelas. Maksud dari tiga kata tersebut, seperti dijabarkan oleh kunandar adalah :

1. Penelitian, ialah aktivitas mencermati suatu objek tertentu melalui metodologi ilmiah dengan mengumpulkan data-data dan dianalisis untuk menyelesaikan suatu masalah.

2. Tindakan, ialah sutau aktivitas yang sengaja dilakukan dengan tujuan tertentu (Suyoto), yang berbentuk siklus kegiatan dengan tujuan memperbaiki atau meningkatkan mutu/kualitas proses belajar-mengajar.

3. Kelas, ialah sekelompok peerta didik yang dalam waktu yang sama menerima pelajaran yang sama dari seorang guru.

Terdapat dua hal pokok dalam penelitian tindakan kelas yang bisa dipetik benang merahnya,yaitu perbaikan dan keterlibatan yang bersifat reflektif. Pada intinya ialah guru memerbaiki proses pengajarannya. Dari beberapa pengertian diatas dapat kita Tarik kesimpulan dalam suatu pemahaman penelitian tindakan kelas merupakan penelitian yang beronteks pada kondisi, keadaan dan situasi yang ada di dalam kelas yang dilaksanakan untuk memecahkan permasalahanpermasalahan yang terjadi guna meningkatkan kualitas pembelajaran di dalam kelas dengan menggunakan aturan sesuai dengan metodologi penelitian. ${ }^{12}$ Tujuan penelitian tindakan kelas, untuk meningkatkan kualitas proses dan hasil pembelajaran di kelas, atau memecahkan masalah pembelajaran di kelas.

11 Suharsimi Arikunto, Prosedur Penelitian Suatu Pendekatan Praktik,(Jakarta: Rineka Cipta, 2010), 79

12 Muh Fitrah, dkk., Teori \& Teknis Penelitian Tindakan Kelas: Alternatif Terbaik Guru dalam Meningkatkan Profesionalisme, (Bandung: Manggu Makmur Tanjung Lestari, 2018), 1617. 


\section{FAKTOR-FAKTOR YANG MENGHAMBAT PELAKSANAAN PENERAPAN METODE PERCAKAPAN DALAM MENINGKATKAN KEMAMPUAN BERBICARA BAHASA ARAB}

Ada beberapa faktor yang menghambat pelaksanaan penerapan metode Percakapan

\section{Tekhnik Pembelajaran Berbicara Bahasa Arab Yang Digunakan Guru Kurang Variatif. ${ }^{13}$}

Perkembangan pembelajaran bahasa Arab di SMA Darul Furqan Kota Bima saat ini masih belum optimal karena teknik-teknik yang diterapkan kurang efektif bagi siswa dalam pembelajaran bahasa Arab.

Metode pengajaran berbicara Bahasa Arab yang digunakan oleh guru bahasa Arab di SMA Darul Furqan sangat terbatas, artinya guru hanya menggunakan metode pembelajaran yang konvensional seperti metode ceramah, sehingga pembelajaran sangat monoton. Guru lebih banyak menjelaskan materi dan siswa mencatat.

Masih banyak siswa yang sulit memahami materi yang diajarkan oleh guru bahasa Arab khususnya, kurang bagusnya penyampaian materi yang diberikan oleh guru, kurangnya kesadaran dan keseriusan siswa dalam belajar, jarang melakukan review kembali materi yang telah disampaikan, kurangnya penguatan dan motivasi dalam setiap pembelajaran.

Sebagaimana yang dinyatakan juga oleh salah seorang siswa sebagai berikut:

"Kami bosan belajar bahasa Arab, karena guru menggunakan metode pengajaran yang kurang membuat kita senang, sehingga kita bosan untuk mengikuti pelajaran bahasa Arab dan teman-teman di dalam kelas juga banyak yang tidur, dan bicara sendiri",14

Di berbagai sekolah pada umumnya masih menitik beratkan kepada metode ceramah, qawaid wa tarjamah dan masih relatif kurang ditopang oleh faktor-faktor pendidikan pengajaran yang memadai. Tidak dipungkiri bahwa

\footnotetext{
${ }^{13}$ Observasi sekolah SMA Darul Furqan Kota Bima, pada tanggal 20 Juli 2019.

${ }^{14}$ Asniati, Wawancara, Kota Bima, Senin 20 Juli 2019
} 
kurikulum memegang peranan penting bagi perjalanan sebuah proses belajar mengajar. Seperti yang dinyatakan oleh guru bahasa Arab berikut:

"Kemampuan anak-anak kelas XI IPA SMA Darul Furqan Kota Bima dalam memahami bahasa Arab masih sangat kurang, karena kurikulum yang ada tidak sesuai dengan kemampuan anakanak, sehingga saya hanya mengajar sekitar masalah yang mudah saja. Karena anak-anak merasa kesulitan dalam memahami bahasa Arab jika saya harus mengajar sesuai dengan tuntutan kurikulum." 15

Pembelajaran bahasa Arab di kelas XI IPA SMA Darul Furqan khususnya, hanya menoton di dalam kelas saja, karena tidak ada konstruksi dari guru itu sendiri untuk mengajarkan berbicara dengan metode yang menarik, siswa belum di terbiasakan mempraktekkan berbicara beserta paam maknanya sehari-hari sebagai proses pkemampuan bahasa Arab dalam kehidupan sehari-hari, sehingga siswa merasa jenuh, bosan dan ngantuk.

\section{E. KESIMPULAN}

Dari penelitian diatas dapat ditarik kesimpulan sebagai berikut.

1. Peningkatkan Hasil Belajar Bahasa Arab Siswa Kelas MA Darul Furqan Kota Bima Dalam meningkatkan keterampilan berbicara Bahasa Arab Dengan Menggunakan Metode Percakapan.

Pada tahap pra siklus peneliti melakukan pengamatan terhadap siswa, dan tes awal untuk mengetahui kemampuan siswa.Dari awal pra siklus ini peneliti menemukan ada 2 siswa atau $10,53 \%$ yang sudah memenuhi standar Ketuntasan Minimal (KKM) yaitu 75.kemudian peneliti mengambil tindakan siklus I, dalam siklus I ini dilakukan melalui beberapa langkah sesuai dengan RPP yaitu: perencanaan, pelaksanaan, pengamatan dan refleksi.

Sesuai dengan beberapa perlakuan yang dilakukan oleh peneliti di atas, setelah menerapkan metode Percakapan untuk meningkatkan kemampuan Bahasa Arab siswa kelas XI IPA SMA Darul Furqan Kota Bima, siswa mengalami peningkatan, sebelum tindakan atau pra siklus jumlah siswa yang mencapai Kriteria Ketuntasan Minimal adalah 2 siswa

\footnotetext{
${ }^{15}$ Alimudin, Wawancara, Kota Bima, 29 Juli 2019
} 
atau $10,53 \%$. Setelah tindakan siklus I kemampuan siswa mengalami peningkatan yaitu sebanyak 9 siswa telah mencapai kriteria ketuntasan minimal atau 47,37\%, dan pada tindakan siklus II dan hasilnya adalah sebanyak 14 siswa telah mencapai kriteria ketuntasan minimal atau sebanyak $73,69 \%$.

2. Faktor-Faktor yang menghambat pelaksanaan Penerapan metode Percakapan Dalam peningkatan kemampuan berbicara Bahasa Arab Siswa Kelas XI IPA Ponpes Darul Furqon Kota Bima

Kenyataan yang dihadapi bahwa sesungguhnya kondisi pengajaran bahasa Arab di Ponpes Darul Furqan Kota Bima masih dihadapkan pada berbagai kendala atau tantangan. Kendala atau tantangan tersebut paling tidak dapat terlihat salah satunya dari segi edukatif. Pengajaran bahasa Arab masih relatif kurang ditopang oleh faktor-faktor pendidikan yang memadai. Faktor-faktor disini diantaranya faktor kurikulum (termasuk di dalamnya orientasi dan tujuan, materi dan metodologi pengajaran, serta sistem evaluasi), tenaga edukatif, sarana, dan prasarana. Oleh karena itu, ada beberapa hal yang menjadi faktor penghambat pelaksanaan strategi pakem dalam peningkatan kemampuan berbicara bahasa Arab Siswa Kelas XI IPA Ponpes Darul Furqan Kota Bima antara lain sebagai berikut:

a. Tekhnik pembelajaran penguasaan mufrodat bahasa Arab yang digunakan guru kurang variatif.

b. Alokasi waktu tidak memadai.

c. Kurikulum .

d. Lingkungan belajar Kurang Mendukung.

\section{F. KRITIK DAN SARAN}

Berdasarkan penelitian yang dilakukan di Ponpes Darul Furqan Kota Bima Kelas XI IPA untuk meningkatkan penguasaan mufrodat bahasa Arab, peneliti mengajukan saran agar tercapainya pembelajaran yang lebih baik, di dalam pembelajaran Bahasa Arab, khususnya dalam menguasai mufrodat bahasa Arab pada Ponpes Darul Furqan Kota Bima, guru lebih kreatif menggunakan metode pembelajaran yang melibatkan peran aktif serta berpikir 
tepat dan kritis siswa, salah satunya seperti metode Percakapan,sehingga suasana kelas lebih menyenangkan. Dan guru harus memberikan latihan latihan untuk mengestimasi pembendaharaan kosa kata bahasa Arab, agar siswa dapat menambah kemampuan berpikir siswa terhadap bahasa Arab.

Pembelajaran bahasa Arab melalui metode Percakapan dapat dijadikan sebagai salah satu solusi untuk meningkatkan prestasi belajar siswa pada mata pelajaran Bahasa Arab. Karena keterlibatan siswa secara aktif, berpikir kritis dan tepat dalam kelas akan mempermudah siswa melatih kemampuan berbicara bahasa Arab.

Dalam penulisan ini masih banyak kesalahan-kesalahan atau kekeliruan baik dalam kata, kalimat maupun penulisan peneliti, oleh karena itu peniliti mengharapkan kritikan dan masukan dari semua pihak, guna memperbaiki pada penulisan selanjutnya.

\section{DAFTAR PUSTAKA}

Izzan Ahmad, Metodologi Pembelajaran Bahasa Arab, Bandung: Humaniora, 2004.

Rohman Fathur, Metodologi Pembelajaran Bahasa Arab, Malang: Madani, 2015.

Hermawan Acep, Metodologi Pembelajaran Bahasa Arab, Bandung: PT Ramaja Kosdakarya, 2018.

Hamid Abdul, Mengukur Kemampuan Berbahasa Arab, Malang: UIN Maliki Pres, 2010.

Hasanah Aan, Pembangunan Profesi Guru, Bandung: CV Pustaka Setia, 2012.

Huda Miftahul, Model - Model Pengajaran Dan Pembelajaran, Yogyakarta: Pustaka Pelajar, 2013.

Irwadin, Faktor Rendahnya Minat Mahasiswa Staim Mengikuti Sholat Berjama'ah Dan Upaya Mengatasinya, Skripsi Serjana Tarbiyah Jurusan PAI, Bima: STAI Muhammadiyah, 2014.

Asrori Imam, Strategi Belajar Bahasa Arab, Malang: Misyikat, 2012.

Sadat Anwar, Perkembangan Kurikulum Bahasa Arab, Yogyakarta: Titah Surga 15.

Arikunto Suharsimi, Penelitian Tindakan Kelas, Yogyakarta: PT Bumi Aksara, 2008.

Purwanto M. Ngalim, Psikologi Pendidikan, Bandung: PT Ramaja Kosdakarya, 2000. 